\title{
Stable Zirconium Carbide Fibers Fabricated by Centrifugal Spinning Technique
}

\author{
CHEN Bowen ${ }^{1,2,3}$, WANG Jingxiao ${ }^{1,2}$, JIANG Youlin ${ }^{1,2,3}$, ZHOU Haijun ${ }^{1,2}$, LIAO Chunjing ${ }^{1,2}$, \\ ZHANG Xiangyu ${ }^{1,2}$, KAN Yanmei ${ }^{1,2}$, NI Dewei ${ }^{1,2}$, DONG Shaoming ${ }^{1,3}$
}

(1. State Key Laboratory of High Performance Ceramics and Superfine Microstructure, Shanghai Institute of Ceramics, Chinese Academy of Sciences, Shanghai 200050, China; 2. Structural Ceramics and Composites Engineering Research Center, Shanghai Institute of Ceramics, Chinese Academy of Sciences, Shanghai 200050, China; 3. University of Chinese Academy of Sciences, Beijing 100049, China)

\begin{abstract}
In this work, an efficient approach was presented to produce stable zirconium carbide (ZrC) fibers by centrifugal spinning technique. Zirconium acetate and sucrose were used as the zirconium source and carbon source respectively. And polyvinyl pyrrolidone (PVP) was used as the spinning aid. After pyrolysis and carbothermal reduction at $1600{ }^{\circ} \mathrm{C}$, the as-spun green fibers can be converted to homogeneous $\mathrm{ZrC}$ fibers composed of uniform nano-sized $\mathrm{ZrC}$ crystals. Moreover, it is revealed that the as-fabricated $\mathrm{ZrC}$ fibers can sustain superior microstructure stability at an ultra-high temperature up to $2000{ }^{\circ} \mathrm{C}$, benefiting from a limited amount of residual carbon. The reaction mechanisms and the resulted $\mathrm{ZrC}$ fibers were also investigated.
\end{abstract}

Key words: zirconium carbide fiber; centrifugal spinning; ultra-high temperature stability

As a member of the ultra-high temperature ceramics (UHTCs) family, zirconium carbide $(\mathrm{ZrC})$ has an extremely high melting point $\left(3540{ }^{\circ} \mathrm{C}\right)$, good mechanical properties, and excellent ablation resistance etc. ${ }^{[1-2]}$, leading to potential applications in the extremely harsh environment associated with hypersonic flight, atmospheric re-entry, and rocket propulsion, etc. ${ }^{[3-5]}$. However, the inherent brittleness and poor thermal shock resistance of bulk ceramics have limited its practical application to some extent.

The fiber reinforced UHTCs matrix composites have excellent mechanical properties, ablation resistance at ultra-high temperatures, and overcome the inherent brittleness and poor thermal shock resistance of bulk UHTCs. The UHTCs fibers, applied as the reinforcement fibers, have become the focus of scientific research in the past few decades ${ }^{[6]}$. To date, $\mathrm{ZrC}$ fibers, act as reinforcement, have been developed through a variety of methods, which are normally achieved based on colloid processing and spinning technique, followed by carbothermal reaction at high temperatures. Using the mixtures of cellulose acetate and zirconium $n$-butoxide as precursor, Kurokawa, et $a l^{[7]}$ prepared $\mathrm{ZrC}$ fibers with short length $(<1 \mathrm{~cm})$ and large diameter $(\sim 100 \mu \mathrm{m})$ by spinning the precursor gel with a syringe. Electrospinning has attracted a lot of attention in fibers fabrication due to its simplicity and ability to fabricate fibers with diameters down to hundreds of nanometers, which is used in the production of $\mathrm{ZrC}$ fibers as well ${ }^{[8]}$. Nam, et $a l^{[9]}$ produced long continuous $\mathrm{ZrC}$ nanofibers by electrospinning and found that the optimized ratio of $\mathrm{C} / \mathrm{Zr}$ was 5.5 as considering the formation of single phase $\mathrm{ZrC}$ with a continuous long fibrous structure. Compared with electrospinning, centrifugal spinning is a highly efficient, low-cost, and versatile method for fibers fabrication. The process uses centrifugal forces coupled with the viscoelastic properties and the mass transfer characteristics of spinning solutions to promote the controlled thinning of a polymer solution filament into fibers. Centrifugal spinning has produced various polymer fibers with good morphologies and high throughput. Recently, Firbas, et $a l^{[10]}$ also developed $\mathrm{ZrC}$ fibers by centrifugal spinning, using zirconium- $n$-propoxide (zirconia source), furfuryl alcohol (carbon source) and polyvinylpyrrolidone (spinning aids) as starting materials. ZrC

\footnotetext{
Received date: 2020-01-13; Revised date: 2020-05-14

Foundation item: The National Key Research and Development Program of China (2016YFB0700202); National Natural Science Foundation of China (51702341); Chinese Academy of Sciences Innovative Funding (CXJJ-17-M169); The Key Deployment Project of Chinese Academy of Sciences (Y71YZ7171G); "CAS Pioneer Hundred Talents Program"

Biography: CHEN Bowen(1994-), male, PhD candidate. E-mail: chenbowen@student.sic.ac.cn

陈博文(1994-), 男, 博士研究生. E-mail: chenbowen@student.sic.ac.cn

Corresponding author: NI Dewei, associate professor. E-mail: deweini@mail.sic.ac.cn 倪德伟，副研究员. E-mail: deweini@mail.sic.ac.cn
} 
fiber can be used as reinforcement in metal matrix composites for nuclear applications, and the extreme service environment askes $\mathrm{ZrC}$ fiber must have an excellent high temperature microstructural stability ${ }^{[11]}$. However, most previous work paid attention to the fabrication process, and the detailed microstructure of the $\mathrm{ZrC}$ fibers after high temperature treatment was not presented. Therefore, investigation of high temperature microstructure stability of the fabricated $\mathrm{ZrC}$ fibers is critical. In this work, zirconium carbide fibers were fabricated by a centrifugal spinning technique based on an aqueous solution-derived precursor, and the conversion mechanisms from as-spun green fibers to $\mathrm{ZrC}$ fibers were investigated in detail. Moreover, the microstructure stability of the synthesized $\mathrm{ZrC}$ fibers was investigated at an ultra-high temperature up to $2000{ }^{\circ} \mathrm{C}$.

\section{Experimental procedure}

\subsection{Materials and processing}

Zirconium acetate $\left(\mathrm{ZrO}\left(\mathrm{CH}_{3} \mathrm{COO}\right)_{2}\right.$, purity $\left.99 \%\right)$, sucrose $\left(\mathrm{C}_{12} \mathrm{H}_{22} \mathrm{O}_{11}\right.$, AR grade $)$ and polyvinyl pyrrolidone (PVP, $\left.M_{\mathrm{W}}=1300000\right)$ were used as raw materials. The molar ratio between $\mathrm{ZrO}\left(\mathrm{CH}_{3} \mathrm{COO}\right)_{2}$ and $\mathrm{C}_{12} \mathrm{H}_{22} \mathrm{O}_{11}$ was set in a range of $4: 1$ to $4: 1.5$ according to the carbothermal reduction reaction between $\mathrm{ZrO}_{2}$ and $\mathrm{C}$. The addition of PVP was fixed at $\sim 2 \mathrm{wt} \%$ of zirconium acetate. To form a uniform precursor, the starting materials were mixed with deionized water under continuous stirring for $24 \mathrm{~h}$. The precursor was injected into the centrifugal spinning (TEADFS-900; Nova Tech Co., Ltd, Beijing, China) spinneret with a $0.5 \mathrm{~mm}$ needle. A collector distance of $20 \mathrm{~cm}$ was used and the rotational frequency was fixed at $8000 \mathrm{r} / \mathrm{min}$. The environmental temperature was set at $45{ }^{\circ} \mathrm{C}$ for the spinning.

The obtained fibers were dried at $85{ }^{\circ} \mathrm{C}$ and then pyrolyzed at $600{ }^{\circ} \mathrm{C}$ for $2 \mathrm{~h}$ under flowing argon atmosphere with a heating rate of $1{ }^{\circ} \mathrm{C} \cdot \mathrm{min}^{-1}$. Subsequently, the fibers were heat-treated at $1400 \sim 1600{ }^{\circ} \mathrm{C}$ for $2 \mathrm{~h}$ in argon at a heating rate of $2{ }^{\circ} \mathrm{C} \cdot \mathrm{min}^{-1}$. Further heat-treatment at $2000{ }^{\circ} \mathrm{C}$ for $2 \mathrm{~h}$ in $\operatorname{argon}$ was conducted to study the microstructure stability of the fibers at ultra-high temperatures.

\subsection{Characterization}

Fourier transform infrared (FT-IR) spectra of the precursors were carried out using NICOLET Is 10 spectrometers (Thermo Fisher Scientific, Massachusetts, USA). Thermogravimetric and differential scanning calorimetric analysis (TG-DSC) were analyzed by Netzsch STA 499 F3 Jupiter ${ }^{\circledR}$ in argon flow in the temperature range of 40-1400 ${ }^{\circ} \mathrm{C}$ at the heating rate of $10{ }^{\circ} \mathrm{C} \cdot \mathrm{min}^{-1}$. Phase compositions were determined by X-ray diffraction (XRD, Rigaku Corporation, Kyoto, Japan) using $\mathrm{Cu}-\mathrm{K} \alpha$ radiation $\left(40 \mathrm{kV}, 40 \mathrm{~mA}, 10\left(^{\circ}\right) / \mathrm{min}\right.$ from $10^{\circ}$ to $\left.85^{\circ}\right)$.

A field emission scanning electron microscope (FESEM, Merlin Compact, Zeiss, Germany) was applied to observe the morphologies and microstructure of the fibers. Besides, a $200 \mathrm{kV}$ transmission electron microscope (TEM, JEOL JEM-2100F, Japan) was also used to characterize the fibers. The oxygen content of the $\mathrm{ZrC}$ fiber was measured by a nitrogen/oxygen determinator (TC600, LECO, St. Joseph, MI). The carbon/sulfur analyzer (CS2000, ELTRA, Germany) was used to determine the carbon content of the as-synthesized fibers.

\section{Results and discussion}

In this work, $\mathrm{ZrC}$ fibers were fabricated via a tailormade centrifugal spinning system. Fig. 1 shows the schematic of the centrifugal spinning device and preparation process of $\mathrm{ZrC}$ fibers. Based on the theory of rotating

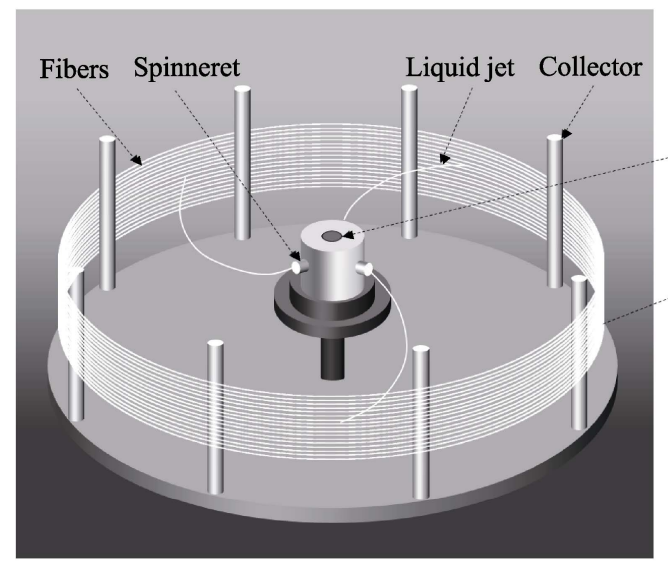

Centrifugal spinning system

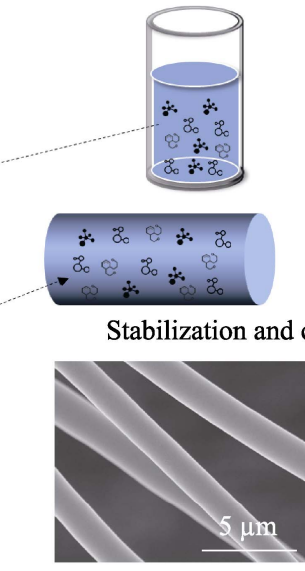

$\mathrm{ZrC}$ fibers
$\mathrm{ZrC}$ precursor

$\therefore \mathrm{ZrO}\left(\mathrm{CH}_{3} \mathrm{COO}\right)_{2}$

$\approx \mathrm{C}_{12} \mathrm{H}_{22} \mathrm{O}_{11}+\& \mathrm{PVP}$

$\diamond \mathrm{H}_{2} \mathrm{O}$

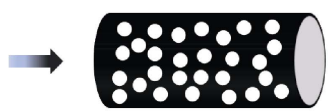

ermal reduction

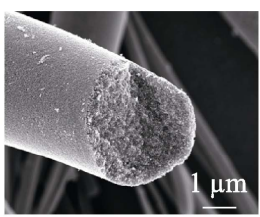

$\mathrm{ZrC}$ fibers heated at $2000{ }^{\circ} \mathrm{C}$

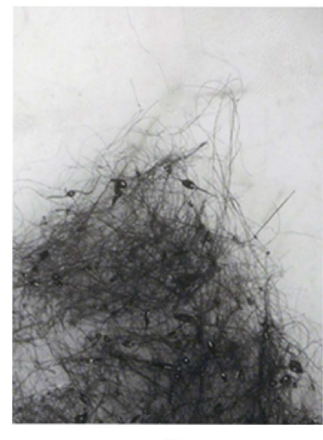

$\mathrm{ZrC}$ fibers

Fig. 1 Schematic of the centrifugal spinning system and the preparation of $\mathrm{ZrC}$ fibers 
centrifuge, the centrifugal spinning device has an adjustable speed motor to provide suitable speed rotation. The distance between the spinneret and collectors can be adjusted to provide a proper space for solvent evaporation. The temperature of the spinning environment can also be controlled. Rotation is initiated after loading the $\mathrm{ZrC}$ precursor into the spinneret. Liquid jets are formed in case the centrifugal force overcome the surface tension, then stretched in the flight of the circular trajectory accompanied by solvent evaporation and deposited on the collectors. After stabilization and carbothermal reduction, $\mathrm{ZrC}$ fibers are obtained. This process is much more efficient as compared with other traditional spinning methods.

Zirconium acetate and sucrose are used as starting reagents, and polyvinyl pyrrolidone (PVP) is used as spinning aid to form a proper precursor for $\mathrm{ZrC}$ fibers. The structural evolution and principal interactions of the $\mathrm{ZrC}$ precursors were investigated by infrared spectroscope. The FT-IR spectra of the precursors with different ratios of $\mathrm{ZrO}\left(\mathrm{CH}_{3} \mathrm{COO}\right)_{2}: \mathrm{C}_{12} \mathrm{H}_{22} \mathrm{O}_{11}$ are shown in Fig. 2, which show similar absorption peaks. The respective assignments of the absorption peaks are $3440(v(\mathrm{O}-\mathrm{H})+$ $\left.v\left(\mathrm{NH}_{2}\right)\right), 2940(v(\mathrm{C}-\mathrm{H})), 1655(v(\mathrm{C}=\mathrm{O})), 1435(v(\mathrm{C}=\mathrm{O})+$ $\delta(\mathrm{CH})), 1030(v(\mathrm{C}-\mathrm{O}-\mathrm{C}))$, and $650\left(\pi\left(\mathrm{C}-\mathrm{CH}_{3}\right)+v(\mathrm{Zr}-\mathrm{O})\right.$ + ring distortion) and 400-500 $(v(\mathrm{Zr}-\mathrm{O})) \mathrm{cm}^{-1[12]}$. With increased $\mathrm{C}_{12} \mathrm{H}_{22} \mathrm{O}_{11}$ content, the peaks at 2940, 1655, $1030,650 \mathrm{~cm}^{-1}$ shift to lower wavenumbers and the intensity of $-\mathrm{C}-\mathrm{O}-\mathrm{C}-,-\mathrm{C}-\mathrm{CH}_{3}$ and $\mathrm{Zr}-\mathrm{O}$ increases slightly. It reveals that the excess sucrose gets involved in complexation. $v(\mathrm{O}-\mathrm{H})$ and $v\left(\mathrm{NH}_{2}\right)$ are corresponding to the broad peak at $\sim 3440 \mathrm{~cm}^{-1}$ which are attributed to the stretching vibration of $-\mathrm{NH}_{2}$ and $-\mathrm{OH}$ groups. The peak at $1655 \mathrm{~cm}^{-1}$ assigned to $v(\mathrm{C}=\mathrm{O})$ is chelated to zirconium, thus drastically reducing the tendency of zirconium to form bulk gels. Furthermore, absorbed water is revealed by the peaks at around 3440 and $1655 \mathrm{~cm}^{-1}$ of the precursor, which is also confirmed by the TG-DSC

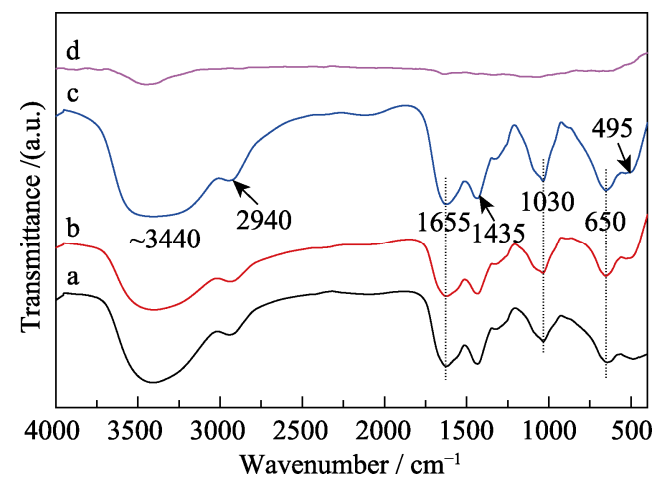

Fig. 2 FT-IR spectra of $\mathrm{ZrC}$ precursors with different $\mathrm{ZrO}\left(\mathrm{CH}_{3} \mathrm{COO}\right)_{2}: \mathrm{C}_{12} \mathrm{H}_{22} \mathrm{O}_{11}$ ratios: (a) $4: 1$; (b) $4: 1.2$; (c) $4:$ 1.5 ; and (d) $\mathrm{ZrC}$ precursor (with $\mathrm{ZrO}\left(\mathrm{CH}_{3} \mathrm{COO}\right)_{2}: \mathrm{C}_{12} \mathrm{H}_{22} \mathrm{O}_{11}=$ $4: 1.5)$ after pyrolysis at $600{ }^{\circ} \mathrm{C}$ analysis as shown below. The peaks located at 650 and $495 \mathrm{~cm}^{-1}$ are attributed to ring distortion $+v(\mathrm{Zr}-\mathrm{O})$ of the cyclic structure after the zirconium chelation ${ }^{[13]}$. Almost all absorption peaks of the precursor disappear after pyrolysis at $600{ }^{\circ} \mathrm{C}$, which indicates that the pyrolysis process finishes and almost no residual organics exists.

As shown in Fig. 3, simultaneous TG-DSC analysis was performed for the as-spun green fibers (using the $\mathrm{ZrC}$ precursor with $\left.\mathrm{ZrO}\left(\mathrm{CH}_{3} \mathrm{COO}\right)_{2}: \mathrm{C}_{12} \mathrm{H}_{22} \mathrm{O}_{11}=4: 1.5\right)$. The pyrolysis processes of the green fibers can be segmented into four steps. The initial weight loss of 5.35\% below $150{ }^{\circ} \mathrm{C}$ is corresponding to the separation of adsorbed water and evaporation of free water. A considerable weight loss of around $9.60 \%$ occurred at the temperature range of $150-190{ }^{\circ} \mathrm{C}$, which is due to the evaporation of constitution water and organic by products. The first two stages lead to an apparent endothermic peak on the DSC curve. The weight loss of around $29.07 \%$ at temperatures between 190 and $500{ }^{\circ} \mathrm{C}$ is corresponding to the decomposition of $\mathrm{ZrO}\left(\mathrm{CH}_{3} \mathrm{COO}\right)_{2}$, $\mathrm{C}_{12} \mathrm{H}_{22} \mathrm{O}_{11}$ and PVP. At temperatures higher than $500{ }^{\circ} \mathrm{C}$, the TG curve is almost flat, where the weak weight loss can be attributed to the continuous carbonization of sucrose and the transformation of the $\mathrm{ZrO}_{2}$ crystalline phase $^{[14-15]}$. After that, the carbothermal reduction reaction begins at around $1400{ }^{\circ} \mathrm{C}$. Therefore, $600{ }^{\circ} \mathrm{C}$ and $1400 \sim 1600{ }^{\circ} \mathrm{C}$ were set as the pyrolysis and carbothermal reduction temperatures, respectively.

Fig. 4 shows the XRD patterns of $\mathrm{ZrC}$ fibers prepared from $\mathrm{ZrC}$ precursors with different $\mathrm{ZrO}\left(\mathrm{CH}_{3} \mathrm{COO}\right)_{2}$ : $\mathrm{C}_{12} \mathrm{H}_{22} \mathrm{O}_{11}$ ratios after heat-treatment at temperature range of $1400-1600{ }^{\circ} \mathrm{C}$. At 1400 and $1500{ }^{\circ} \mathrm{C}, \mathrm{ZrC}$ forms in the fibers but $t-\mathrm{ZrO}_{2}$ still exists. Cubic $\mathrm{ZrC}$ becomes the only phase for all three $\mathrm{ZrC}$ fibers at $1600{ }^{\circ} \mathrm{C}$, where the oxygen content is determined around $1 \mathrm{wt} \%$. As shown in the expanded XRD (inset in Fig. 4),

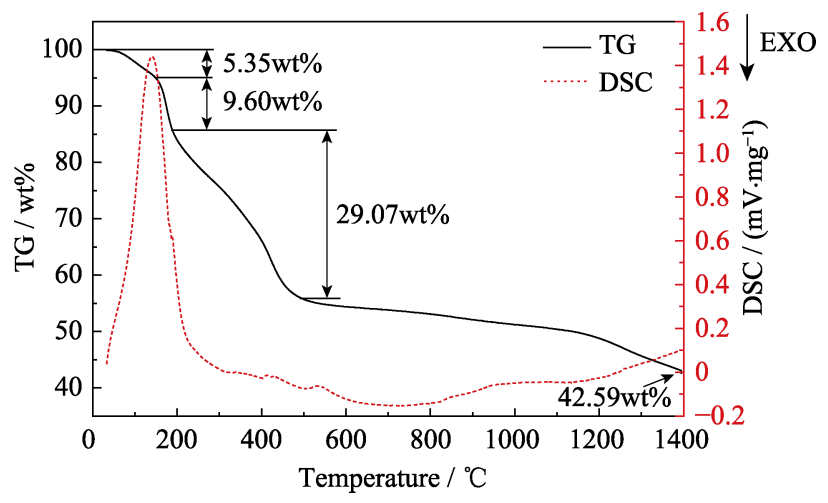

Fig. 3 TG-DSC curves of the as-spun green fibers prepared from $\mathrm{ZrC}$ precursor with $\mathrm{ZrO}\left(\mathrm{CH}_{3} \mathrm{COO}\right)_{2}: \mathrm{C}_{12} \mathrm{H}_{22} \mathrm{O}_{11}=4: 1.5$ 


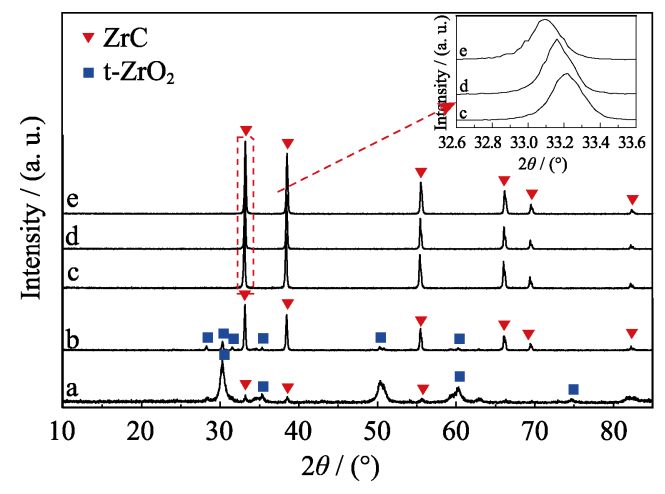

Fig. $4 \mathrm{XRD}$ patterns of $\mathrm{ZrC}$ fibers prepared from $\mathrm{ZrC}$ precursors with different $\mathrm{ZrO}\left(\mathrm{CH}_{3} \mathrm{COO}\right)_{2}: \mathrm{C}_{12} \mathrm{H}_{22} \mathrm{O}_{11}$ ratios after heattreatment at temperature range from 1400 to $1600{ }^{\circ} \mathrm{C}$ for $2 \mathrm{~h}$

(a) $4: 1.5 @ 1400{ }^{\circ} \mathrm{C}$; (b) $4: 1.5 @ 1500{ }^{\circ} \mathrm{C}$; (c) $4: 1.5 @ 1600{ }^{\circ} \mathrm{C}$; (d) $4: 1.2 @ 1600{ }^{\circ} \mathrm{C}$; (e) $4: 1 @ 1600{ }^{\circ} \mathrm{C}$

the diffraction peaks shift to lower theta value with the decrease of sucrose in the $\mathrm{ZrC}$ precursor. According to the Bragg equation, the lattice parameter of the cubic $\mathrm{ZrC}$ was calculated to be $0.46631,0.46706$, and $0.46781 \mathrm{~nm}$ respectively. This implies the formation of non-stoichiometric $\mathrm{Zr}_{1-x} \mathrm{C}$ according to the reaction of $(1-x) \mathrm{ZrC}+x \mathrm{C} \rightarrow \mathrm{Zr}_{1-x} \mathrm{C}$. More $\mathrm{Zr}$ vacancies/non-stoichiometric $\mathrm{Zr}_{1-x} \mathrm{C}$ can be formed with the increase of residual free carbon ( $x$ value), resulting in a smaller lattice parameter. In previous work, Raman spectra of the synthesized fibers are caricatured. The results indicate that two typical peaks centered at $\sim 1330$ and $\sim 1590 \mathrm{~cm}^{-1}$ are detected in all three samples, corresponding to the $\mathrm{D}$ and $\mathrm{G}$ peaks of free carbon. The results reveal the presence of the residual free carbon in the fibers. Chemical analysis indicates that the contents of the residual free carbon in the synthesized $\mathrm{ZrC}$ fibers are $1.4 \mathrm{wt} \%, 0.8 \mathrm{wt} \%$, and $0.5 \mathrm{wt} \%$, respectively ${ }^{[16]}$. Base on the XRD results, the grain sizes of fibers are calculated by the Debye-Scherrer equation. The grain sizes of the $\mathrm{ZrC}$ fibers obtained from the precursor with $\mathrm{ZrO}\left(\mathrm{CH}_{3} \mathrm{COO}\right)_{2}: \mathrm{C}_{12} \mathrm{H}_{22} \mathrm{O}_{11}$ ratio of $4: 1,4: 1.2$ and $4: 1.5$ are $32.54,30.90$, and $24.23 \mathrm{~nm}$ respectively. The content of the residual carbon increases with the decrease of the $\mathrm{ZrO}\left(\mathrm{CH}_{3} \mathrm{COO}\right)_{2}: \mathrm{C}_{12} \mathrm{H}_{22} \mathrm{O}_{11}$ ratio. And, the existence of the residual carbon impedes the surface diffusion between $\mathrm{ZrC}$ grains which prevents the growth of $\mathrm{ZrC}$ grains during the heat treatment process.

SEM and TEM were used to study the microstructure evolution of the $\mathrm{ZrC}$ fibers. As shown in Fig. 5(a), the diameter of as-spun green fibers is around $1-3 \mu \mathrm{m}$. It shows a uniform distribution and certain bridges among fibers can be observed. This indicates that the synthesized ZrC precursor solution presents very good spin-ability. Although zirconium acetate, sucrose, and PVP are decomposed and a large number of gas molecules run out
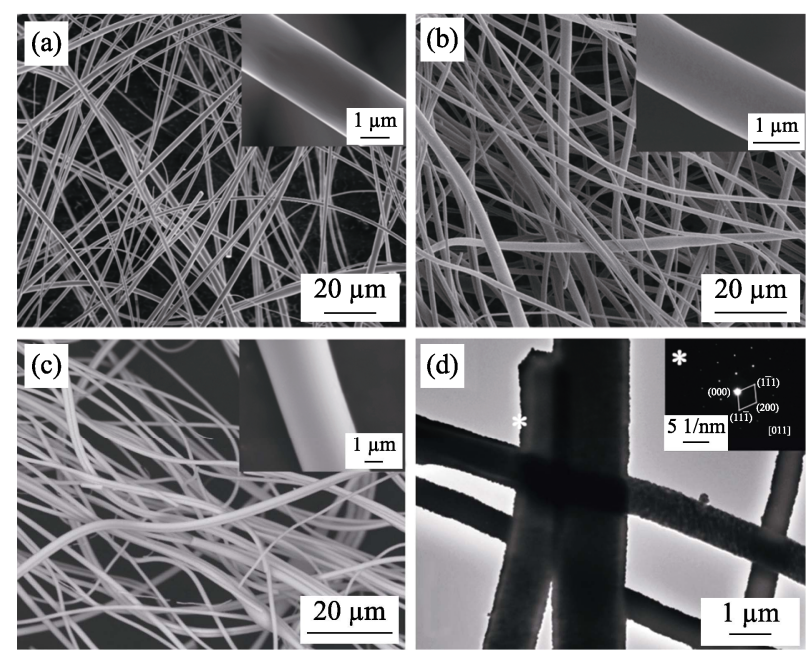

Fig. 5 SEM images of $\mathrm{ZrC}$ fibers prepared from $\mathrm{ZrC}$ precursor with $\mathrm{ZrO}\left(\mathrm{CH}_{3} \mathrm{COO}\right)_{2}: \mathrm{C}_{12} \mathrm{H}_{22} \mathrm{O}_{11}=4: 1.5((\mathrm{a})$ as-spun green fibers; (b) after heat-treatment at $600{ }^{\circ} \mathrm{C}$ and (c) after heattreatment at $1600{ }^{\circ} \mathrm{C}$ ); and (d) TEM image of $\mathrm{ZrC}$ fibers after heat-treatment at $1600{ }^{\circ} \mathrm{C}$

The insets in $(a, b, c)$ are the corresponding local enlarged images; while the inset in (d) is the selected area electron diffraction (SAED) pattern of $\mathrm{ZrC}$ fibers

during the pyrolysis at $600{ }^{\circ} \mathrm{C}$, there's no obvious change in the morphology of the fibers (Fig. 5(b)). After heat-treated at $1600{ }^{\circ} \mathrm{C}$, the morphology of the $\mathrm{ZrC}$ fibers is well preserved, where the surface is smooth and the diameter does not change obviously (Fig. 5(c)). TEM image and SAED pattern shown in Fig. 5(d) confirm that the fibers are composed of well crystallized $\mathrm{ZrC}$ nanoparticles (inset in Fig. 5(d)).

Subsequently, the microstructure stability of the synthesized $\mathrm{ZrC}$ fibers at an ultra-high temperature of $2000{ }^{\circ} \mathrm{C}$ was investigated. Fig. 6 shows SEM images of the $\mathrm{ZrC}$ fibers prepared from $\mathrm{ZrC}$ precursors with different $\mathrm{ZrO}\left(\mathrm{CH}_{3} \mathrm{COO}\right)_{2}: \mathrm{C}_{12} \mathrm{H}_{22} \mathrm{O}_{11}$ ratios after heat-treated at $2000{ }^{\circ} \mathrm{C}$ for $2 \mathrm{~h}$ under flowing argon atmosphere. The morphologies and high temperature microstructure stability of the $\mathrm{ZrC}$ fibers are strongly influenced by the composition of the initial $\mathrm{ZrC}$ precursors. For the $\mathrm{ZrC}$ fibers prepared from the precursor with higher $\mathrm{ZrO}\left(\mathrm{CH}_{3} \mathrm{COO}\right)_{2}: \mathrm{C}_{12} \mathrm{H}_{22} \mathrm{O}_{11}$ ratio $(4: 1)$, the $\mathrm{ZrC}$ grains of the fibers coarsen seriously and the fibrous structures are destroyed after heat-treated at $2000{ }^{\circ} \mathrm{C}$ (Fig. 6(a-b)). While for the fibers prepared from $\mathrm{ZrC}$ precursors with increased sucrose content, the fibrous structures are well preserved with a smooth surface and limited $\mathrm{ZrC}$ grains coarsening (Fig. 6(c-f)). As discussed on the XRD patterns (Fig. 4), residual free carbon exists in the $\mathrm{ZrC}$ fibers with the increase of sucrose in the initial precursors. Therefore, it is indicated that the existence of residual carbon is beneficial to retain the morphologies and 

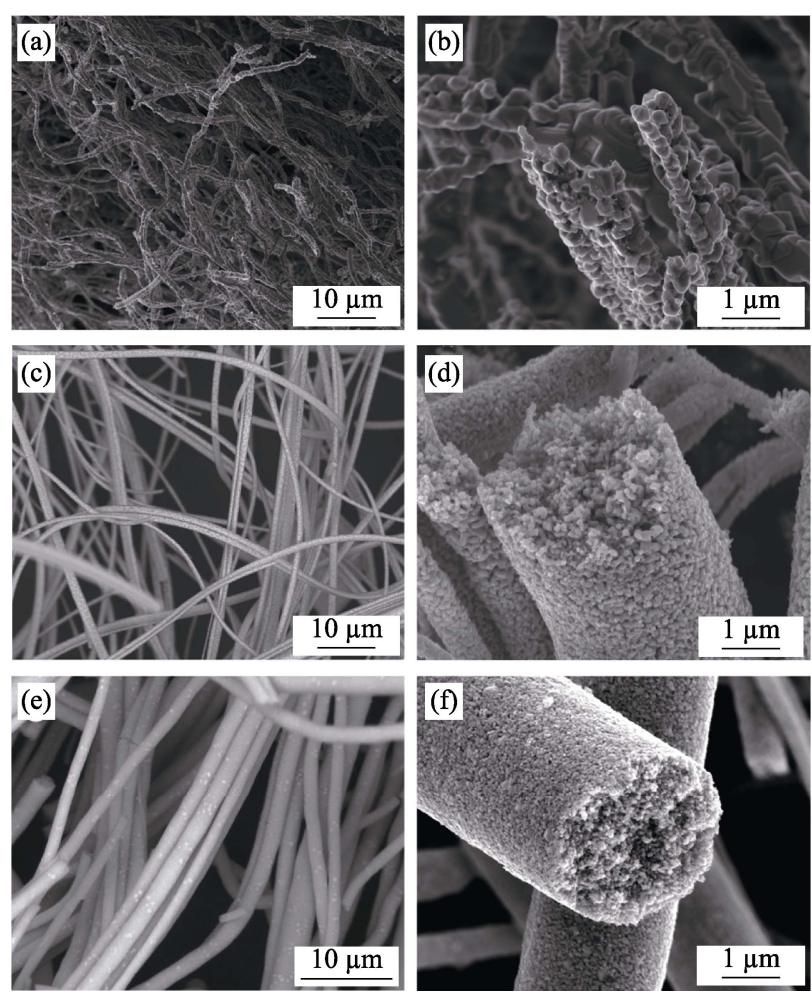

Fig. $6 \mathrm{SEM}$ images of $\mathrm{ZrC}$ fibers prepared from $\mathrm{ZrC}$ precursors with different $\mathrm{ZrO}\left(\mathrm{CH}_{3} \mathrm{COO}\right)_{2}: \mathrm{C}_{12} \mathrm{H}_{22} \mathrm{O}_{11}$ ratios after heat-treatment at $2000{ }^{\circ} \mathrm{C}$ for $2 \mathrm{~h}$

(a, b) $4: 1$; (c, d) $4: 1.2$; (e, f) $4: 1.5$

improve the high temperature microstructure stability of the $\mathrm{ZrC}$ fibers. As is known, grain growth mainly occurred among particles via surface diffusion. The existence of the limited amount of residual carbon in the $\mathrm{ZrC}$ fibers reduces the $\mathrm{ZrC}$ particles' mutual contact, thus preventing the particle coarsening at high temperature and improve the microstructure stability of the fibers up to $2000{ }^{\circ} \mathrm{C}$. It can be seen from the cross-sections of the fibers (Fig. $6(\mathrm{~d}, \mathrm{f})$ ) that the $\mathrm{ZrC}$ grain size of the fibers remains about tens of nanometers even after heat-treated at $2000{ }^{\circ} \mathrm{C}$.

\section{Conclusions}

In summary, $\mathrm{ZrC}$ fibers with ultra-high temperature microstructure stability were successfully prepared by a combination of solution-based processing and centrifugal spinning technique. Zirconium acetate, sucrose, and polyvinyl pyrrolidone (PVP) are used as the zirconium source, carbon source, and spinning aid respectively. The as-spun green fibers are converted to homogeneous $\mathrm{ZrC}$ fibers composed of uniform nano-sized $\mathrm{ZrC}$ crystals after pyrolysis and carbothermal reduction reaction at $1600{ }^{\circ} \mathrm{C}$. The results show that the small amount of residual free carbon in the fibers can react with $\mathrm{ZrC}$ and cause the formation of non-stoichiometric $\mathrm{Zr}_{1-x} \mathrm{C}$. Furthermore, the existence of residual free carbon can prevent $\mathrm{ZrC}$ particle coarsening and lead to excellent high-temperature microstructure stability of the synthesized $\mathrm{ZrC}$ fibers up to $2000{ }^{\circ} \mathrm{C}$. It is believed that the $\mathrm{ZrC}$ fiber with hightemperature microstructure stability would be beneficial for the subsequent application of the materials.

\section{References:}

[1] FAHRENHOLTZ W G, HILMAS G E, TALMY I G, et al. Refractory diborides of zirconium and hafnium. J. Am. Ceram. Soc., 2007, 90(5): $1347-1364$.

[2] ZHANG G J, NI D W, ZOU J, et al. Inherent anisotropy in transition metal diborides and microstructure/property tailoring in ultrahigh temperature ceramics-a review. J. Eur. Ceram. Soc., 2018, 38(2): 371-389.

[3] CHARBONNIER F M, MACKIE W A, HARTMAN R L, et al. Robust high current field emitter tips and arrays for vacuum microelectronics devices. J. Vac. Sci. Technol, B: Microelectron. Nanometer. Struct., 2001, 19(3): 1064-1072.

[4] COCKERAM B V, MEASURES D P, MUELLER A J. The development and testing of emissivity enhancement coatings for themophotovoltaic (TPV) radiator applications. Thin Solid Films, 1999, 355(1): 17-25.

[5] SHEATS J R, MACKIE W A, ANZ S, et al. Polymer electroluminescent devices with zirconium carbide cathodes. Pro. SPIE - Int. Soc. Opt. Eng., 1997, 3148: 219-227.

[6] LI F, KANG Z, HUANG X, et al. Fabrication of zirconium carbide nanofibers by electrospinning. Ceram. Int., 2014, 40(7): 10137-10141.

[7] KUROKAWA Y, OTA H, SATO T. Preparation of carbide fibres by thermal decomposition of cellulose-metal (Ti, Zr) alkoxide gel fibres. J. Mate. Sci. Lett., 1994, 13(7): 516-518.

[8] CUI X M, NAM Y S, LEE J Y, et al. Fabrication of zirconium carbide $(\mathrm{ZrC})$ ultra-thin fibers by electrospinning. Mater. Lett., 2008, 62(12/13): 1961-1964.

[9] NAM Y S, CUI X M, JEONG L, et al. Fabrication and characterization of zirconium carbide $(\mathrm{ZrC})$ nanofibers with thermal storage property. Thin Solid Films, 2009, 517(24): 6531-6538.

[10] FIRBAS P, SEEBER A, CHENG Y B. Creation of titanium and zirconium carbide fibers with the forcespinning technique. Int. $J$. App. Ceram. Technol., 2016, 13(4): 619-628.

[11] SHE J, ZHAN Y, PANG M, et al. In situ synthesized $\left(\mathrm{ZrB}_{2}+\mathrm{ZrC}\right)$ hybrid short fibers reinforced $\mathrm{Zr}$ matrix composites for nuclear applications. Int. J. Refract. Met. Hard Mater., 2011, 29(3): 401-404.

[12] LIU H Y, HOU X Q, WANG X Q, et al. Fabrication of high-strength continuous zirconia fibers and their formation mechanism study. J. Am. Ceram. Soc., 2004, 87(12): 2237-2241.

[13] TAO X, QIU W, LI H, et al. Synthesis of nanosized zirconium carbide from preceramic polymers by the facile one-pot reaction. Polym. Adv. Technol., 2010, 21(4): 300-304.

[14] DONG Z, ZHANG X, HUANG Q, et al. Synthesis and pyrolysis behavior of a soluble polymer precursor for ultra-fine zirconium carbide powders. Ceram. Int., 2015, 41(6): 7359-7365.

[15] LI F, LIANG M, MA X F, et al. Preparation and characterization of stoichiometric zirconium carbide foams by direct foaming of zirconia sols. J. Porous Mater, 2015, 22(2): 493-500.

[16] WANG J X, NI D W, DONG S M, et al. Synthesis of nanocrystallized zirconium carbide based on an aqueous solution-derived precursor. $R S C A d v$. 2017, 37(7): 22722-22727. 


\section{基于离心纺丝技术制备稳定的碳化锆纤维}

陈博文 ${ }^{1,2,3}$, 王敬晓 ${ }^{1,2}$, 姜佑霖 ${ }^{1,2,3}$, 周海军 ${ }^{1,2}$, 廖春景 ${ }^{1,2}$, 张翔宇 ${ }^{1,2}$, 阚艳梅 ${ }^{1,2}$, 倪德伟 ${ }^{1,2}$, 董绍明 ${ }^{1,3}$

(1. 中国科学院 上海硅酸盐研究所高性能和超微结构国家重点实验室, 上海 200050; 2. 中国科学院 上海硅酸盐 研究所 结构陶瓷与复合材料工程研究中心，上海 200050; 3. 中国科学院大学，北京 100049)

摘 要: 本研究提出了一种利用离心纺丝技术制备稳定碳化锆 $(\mathrm{ZrC})$ 纤维的有效方法。此方法使用醋酸锆和蔗糖作为 锆源和碳源, 聚乙烯吡咯烷酮(PVP)作为纺丝助剂, 经过 $1600{ }^{\circ} \mathrm{C}$ 的裂解与碳热还原热处理后, 所纺原丝转化成由 均匀纳米 $\mathrm{ZrC}$ 晶体组成的 $\mathrm{ZrC}$ 纤维。研究结果表明, 纤维中残留的少量碳可助力 $\mathrm{ZrC}$ 纤维在 $2000{ }^{\circ} \mathrm{C}$ 的超高温环 境下仍保持较好的结构稳定性。

关 键 词: $\mathrm{ZrC}$ 纤维; 离心纺丝; 超高温稳定性

中图分类号: TQ174 文献标识码: A 